\title{
Comparison of Shoot Water Potential in Plantation and Natural Forest Trees of Haloxylon ammodendron (C.A.Mey) Bunge ex Fenzl Desert Region, Mongolia
}

\author{
Enkhchimeg Tsedensodnom ${ }^{1}$, Ser-Oddamba Byambadorj ${ }^{2}$, Narantugs \\ Dulamsuren $^{2}$, Khaulanbek Akhmadi ${ }^{1}$, Batkhuu Nyam-Osor ${ }^{2, *}$ \\ ${ }^{1}$ Institute of Geography and Geoecology, Mongolian Academy of Sciences, Ulaanbaatar, Mongolia \\ ${ }^{2}$ Laboratory of Forest Genetics and Ecophysiology, Department of Environment and Forest Engineering, \\ National University of Mongolia, Ulaanbaatar, Mongolia \\ *Corresponding author. Email: nbatkhuu@gmail.com
}

\begin{abstract}
Haloxylon ammodendron (C.A.Mey) Bunge ex Fenzl, (Saxaul forest) is a small tree and shrub belonging to the genus Amaranthaceae. We measured shoot water potential of saxaul trees, indirectly determined the current status of shoot water potential of natural forests and planted trees, the adaptability of planted trees, and assessed the adaptation of natural saxaul trees to drought. The study was conducted Bayanzag region, Umnugobi province, Mongolia. The assimilation shoot water potential was measured in natural trees differing in their age classes: adult tree $(\leq 200 \mathrm{~cm})$, young tree $(80-200 \mathrm{~cm})$, and juvenile $(\geq 80 \mathrm{~cm})$ according to their stem height classes. Meanwhile, planted trees were classified as $50 \mathrm{~cm}, 100 \mathrm{~cm}$, and $140 \mathrm{~cm}$ in by stem height, and stem diameter and tree height were measured. The comparative measurements of shoot water potential revealed that young and juvenile trees are more subject to water stress than adult trees, which shows their adaptation performance in drought conditions. Similar patterns were observed in planted juvenile trees (up to $80 \mathrm{~cm}$ ), either planted by seedlings or direct seeding. As young trees grew taller, their susceptibility to water stress decreased. Natural forest trees had lower shoot water potential values or were more susceptible to water deficit than regularly watered planted trees. In the case of the planting and watering method, hole planting and watering may be more effective than direct seeding and furrow watering, as measured by the shoot water potential measurements.
\end{abstract}

Keywords: Saxaul, restoration, irrigations, shoot water potential, drought

\section{INTRODUCTION}

Haloxylon ammodendron (C.A.Mey) Bunge ex Fenzl, (Saxaul forest) is a small tree and shrub belonging to the genus Amaranthaceae. Saxaul forest covers a small geographic area, growing in Afghanistan, Iran, Kazakhstan, Kyrgyzstan, Tajikistan, Turkmenistan, Uzbekistan, Mongolia, and northern China, including Inner Mongolia, Xinjiang $[1 ; 2 ; 3]$. Saxaul is arid, with harsh desert conditions, low precipitation for long periods $[4 ; 5 ; 6 ; 7]$, and able withstand salinity, poor soils, high light intensity, and has an adaptative life cycle [8]. Saxaul is widely used for afforestation and rehabilitation in the arid regions of the Gobi desert in Mongolia and northern China $[9 ; 10 ; 11 ; 12]$. Saxaul forests amount to a total of 3825922 ha in the southern part of Mongolia. Over the past few decades, due to desertification, land degradation, and human activities, the distribution and resources of Saxaul forests have decreased and natural regeneration has been inhibited. Therefore, there is an urgent need to protect and rehabilitate Saxaul forests by providing high quality seedlings and establishing forest strips [11]. Since 2011, afforestation by planting Saxaul seedlings has been undertaken in Bayanzag region within the framework of the joint Mongolia-Korea "Greenbelt" plantation project $[13 ; 14]$. Saxaul 
forests cover 23488 ha within the vicinity of the project site, of which 20800 ha are continuously distributed, 2688 ha are scattered forest, and 2304 ha are under regional protection status. Afforestation was carried out on 1450 ha during the project implementation period and there is a necessity of monitoring planted trees in comparision with natural forests by determining their physiological characteristics [13]. Water is an assential resource needed for plant growth and development, and nutrient carrier plants require large amounts of water. Most crop plants need regular irrigation, and often water stress results in yield decrease or lower product quality [15]. Desert plants, like any other plants, need water to grow, and this explains why their survival is often poor especially in arid environments. Hence, several desert plants present adaptations aimed at avoiding water loss, such as the prepuce of a thick cuticle, hairy pubescence which creates a thicker boundary layer on the leaf surface, sunken stomata, and succulence (storage tissue with large amounts of water) [16]. In addition, these plants develop longer roots to reach the groundwater table. The physical pressure required to transpirate water from a leaf is defined as the water potential of the leaf [17]. The main objectives of this study are: comparative analysis of the shoot water potential and determining soil moisture content of natural and planted saxaul trees.

\section{MATERIALS AND METHODS}

\subsection{Study area}

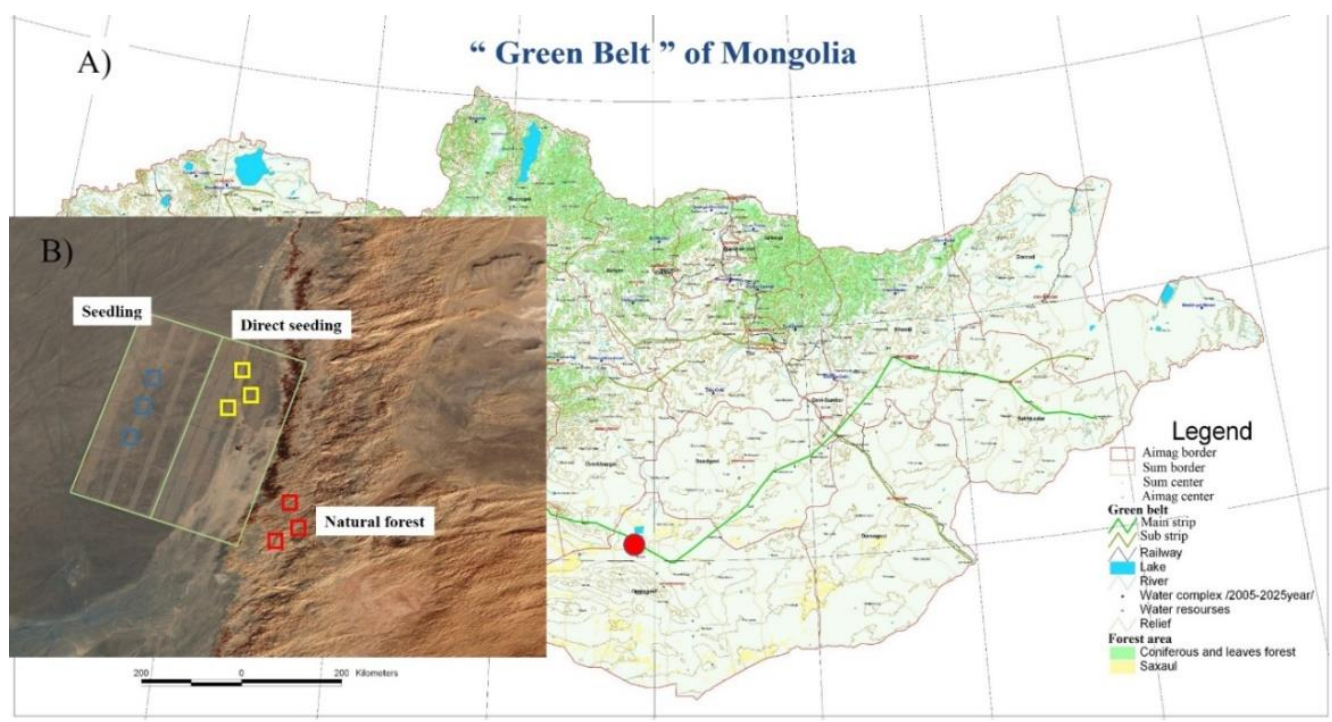

Figure 1. A) Map of Mongolia; the red square indicating the location of the study site; B) aerial photo with a close-up of the study site (red square is natural forest; yellow square is direct seeding; blue square is Bulgan soum, Umnugobi province, Mongolia. (Figure 1A). This region has a continental, arid, temperate climate with hot dry summers and cold winters. The area receives a mean precipitation of $137 \mathrm{~mm}$ per year (measured at Saikhan weather station in Bulgan soum), $80 \%$ to $90 \%$ of which is in the summer and autumn months. Mean annual air temperature is $6.2 \pm 1.1^{\circ} \mathrm{C}$, and this increases to $19.8 \pm 0.45^{\circ} \mathrm{C}$ during the summer, with a minimum winter temperature (January) and a maximum summer (July) temperature of $-13.8^{\circ} \mathrm{C}$ and $24.2^{\circ} \mathrm{C}$, respectively. (Figure 2A). Relative air humidity and temperature at the study site during the measurement day is shown (Figure 2B). Field measurements were conducted in early July 2017 in natural and plantation forest sites. Two monitoring sites were established at the edge of natural saxaul forest $\left(44^{\circ} 10^{\prime} 57.7^{\prime \prime} \mathrm{N}\right.$, $103^{\circ} 41^{\prime} 52.2^{\prime \prime} \mathrm{E}, 1134 \mathrm{~m}$ asl), and plantation forests $\left(44^{\circ} 10^{\prime} 32.9^{\prime \prime} \mathrm{N}, 103^{\circ} 44^{\prime} 08^{\prime \prime} \mathrm{E}, 1110 \mathrm{~m}\right.$, asl). The plantation forest was established in 2012 using two types of planting methods, planting containerized seedlings and direct seedings. Seedlings were planted in strips with a $5 \mathrm{~m}$ distance, spacing between seedlings were $2 \mathrm{~m}$. Direct seeding was conducted with 1.2 gr per 1 meter length of strip (Figure 1B). The monitoring plots $(30 \times 30 \mathrm{~m})$ were established with three replicates at each study site. Trees in natural forests were divided into a) $\leq 200 \mathrm{~cm}$; b) 80 $200 \mathrm{~cm}$; c) $\geq 80 \mathrm{~cm}$; based on their stem height; meanwhile, trees in plantation forests were divided into a) $\geq 50 \mathrm{~cm}$, b) $100 \mathrm{~cm}$, and c) $\leq 140 \mathrm{~cm}$, respectively.

\footnotetext{
containerized seedling)
} 

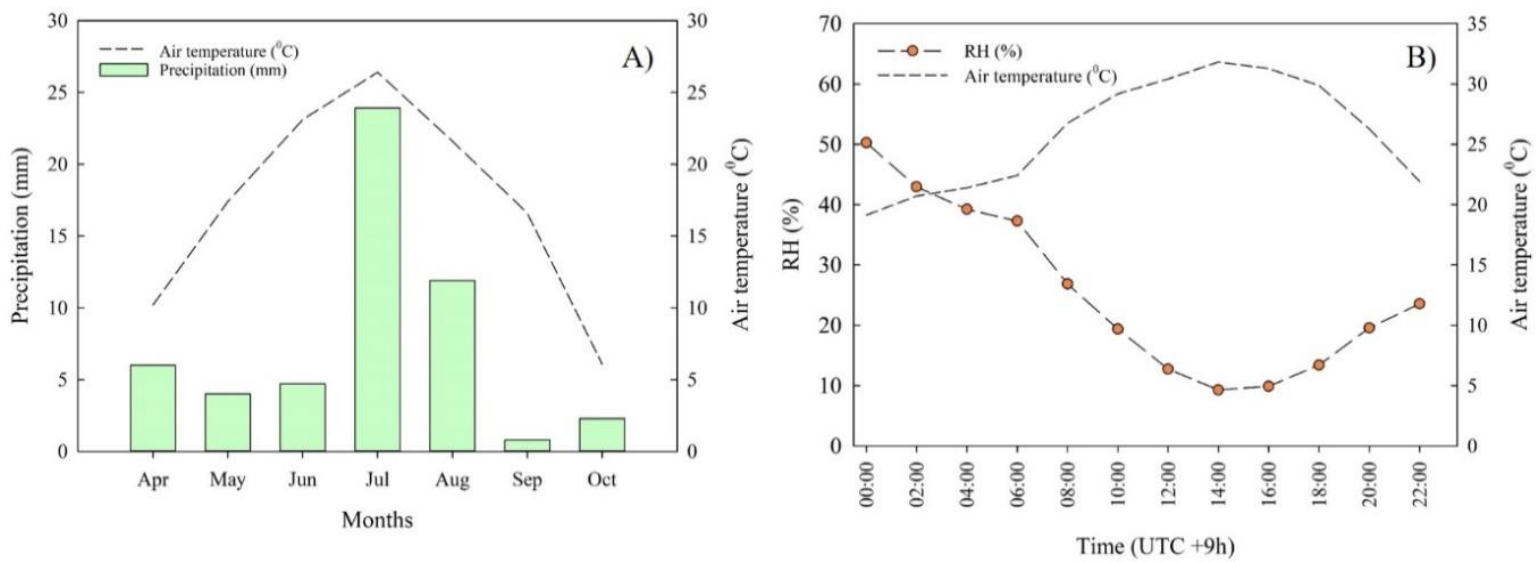

Figure 2. A) Mean monthly air temperature (broken line) and precipitation (bar) in the study site during the growing season (i.e., April-October 2017). B) air temperature during the measurement day (broken line) and relative humidity (round dotted line) (i.e., 03, July 2017). Data were obtained during implementation of the experiments (HOBO H21-USB Micro Station, Onset Computer Corp, USA).

\subsection{Measurement of shoot water potential}

Shoot water potentials (MPa) were determined by using a pressure chamber (Model 1505D EXP, PMS Instrument Company, Albany, Oregon, USA) following the procedures of Scholander [18]. Measurements were conducted in three randomly chosen healthy trees with sun-exposed assimilation shoots (c.a., 0.4-1.5 $\mathrm{m}$ above the ground), with three replications at each site. The water potential of the shoot was measured between 02:00-19:00 with four hour intervals.

\subsection{Soil moisture content}

Soil moisture content was measured using a Hydro Sense II Soil Moisture Measurement System (Campbell Scientific Australia). Measurements were made 5 times from the soil inside the crown circle of each tree during with the shoot water potential measurement.

\subsection{Statistical analysis}

Statistical analysis was done by using JMP 5.1.2 and comparative analysis was conducted with ANOVA [19].

\section{RESULTS AND DISCUSSION}

The measurements of shoot water potential of natural forest trees were not significantly different in terms of tree height $(p=0.146)$, but a significant difference was found between measured hours $(\mathrm{p}<.0002)$. Shoot water potential $\leq 200 \mathrm{~cm}$ trees at 13:00 (-2.78 $\pm 0.12 \mathrm{MPa}), 80-200 \mathrm{~cm}$ trees at 09:00 ($2.24 \pm 0.10 \mathrm{MPa}$ ), and trees up to $\geq 80 \mathrm{~cm}$ at 09:00 (-
$3.22 \pm 0.16 \mathrm{MPa}$ ) had the lowest value and the highest evaporation at the time of measurement. Diurnal measurement of shoot water potential revealed that the lowest values of potential were measured at 09:00 and 13:00, or water decreased, and then gradually increased from 15:00 to the highest value at 02:00 before predawn (Figure 3A).

Soil moisture content did not differ among tree heights $(\mathrm{p}=0.857)$, and soil moisture around taller trees $(0.67 \pm 0.10 \%)$ was higher than that of smaller trees $(0.27 \pm 0.02 \%)$. The highest value of soil

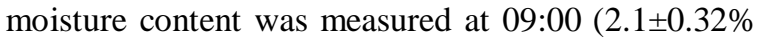
for $\leq 200 \mathrm{~cm}$ trees; $1.6 \pm 0.19 \%$ for $80-200 \mathrm{~cm}$ trees; and $1.3 \pm 0.05 \%$ for $\geq 80 \mathrm{~cm}$ trees, respectively.

The shoot water potential of the containerized seedlings trees differed within tree height classes $(\mathrm{p}<.07)$. Meanwhile, no significant difference was observed between measurement hours $(p=0.35)$. In terms of tree height, the lowest water potential values were observed at $50 \mathrm{~cm}(-1.84 \pm 0.03 \mathrm{MPa})$ and 100 $\mathrm{cm}(-1.79 \pm 0.03 \mathrm{MPa})$, and $140 \mathrm{~cm}(-2.07 \pm 0.02 \mathrm{MPa})$ at 13:00 (Figure 3B).

The soil moisture content around the $\leq 140 \mathrm{~cm}$ tree increased at 02:00 and 05:00 (4.5 $\pm 1.2 ; 4.1 \pm 1.3 \%)$ and decreased sharply between 09:00 and 13:00 (1.6 \pm 0.3 , $2.1 \pm 1.02 \%$ ). In addition, the soil moisture content of the $100 \mathrm{~cm}$ tree was stable between $2.7 \pm 0.27 \%$ to $3.2 \pm 0.47 \%$. Soil moisture content of the $\geq 50 \mathrm{~cm}$ tree was highest at 02:00 (4.56 \pm 0.90$)$, then decreased at

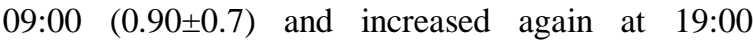
$(3.0 \pm 1.3)$

The shoot water potential of direct seeding trees differed by tree height and between measured hours $(\mathrm{p}<.01 ; \mathrm{p}<.0001)$. The lowest values were observed 
in $\leq 140 \mathrm{~cm}(-2.61 \pm 0.32 \mathrm{MPa}) ; 100 \mathrm{~cm}(-2.00 \pm 0.22$ $\mathrm{MPa}) ; \geq 50 \mathrm{~cm}(-1.53 \pm 0.23 \mathrm{MPa})$ at 09:00. As trees grew taller, they were more exposed to water deficits (Figure 3C).

The soil moisture content of $\leq 140 \mathrm{~cm}$ tree was relatively stable during the day (average 1.47\%). Also, around the $100 \mathrm{~cm}$ trees the soil water content decreased sharply at 05:00 $(0.2 \pm 0.1 \%)$, increased at 09:00 (1.06 $\pm 0.2 \%)$, and decreased again at 13:00 $(0.13 \pm 0.1 \%)$. In addition, around $\geq 50 \mathrm{~cm}$ trees, were highest $(4.5 \pm 1.0 \%)$ at 02:00, decreased at 09:00 $(1.6 \pm 0.28 \%)$, and increased at 13:00, increasing the soil water content.
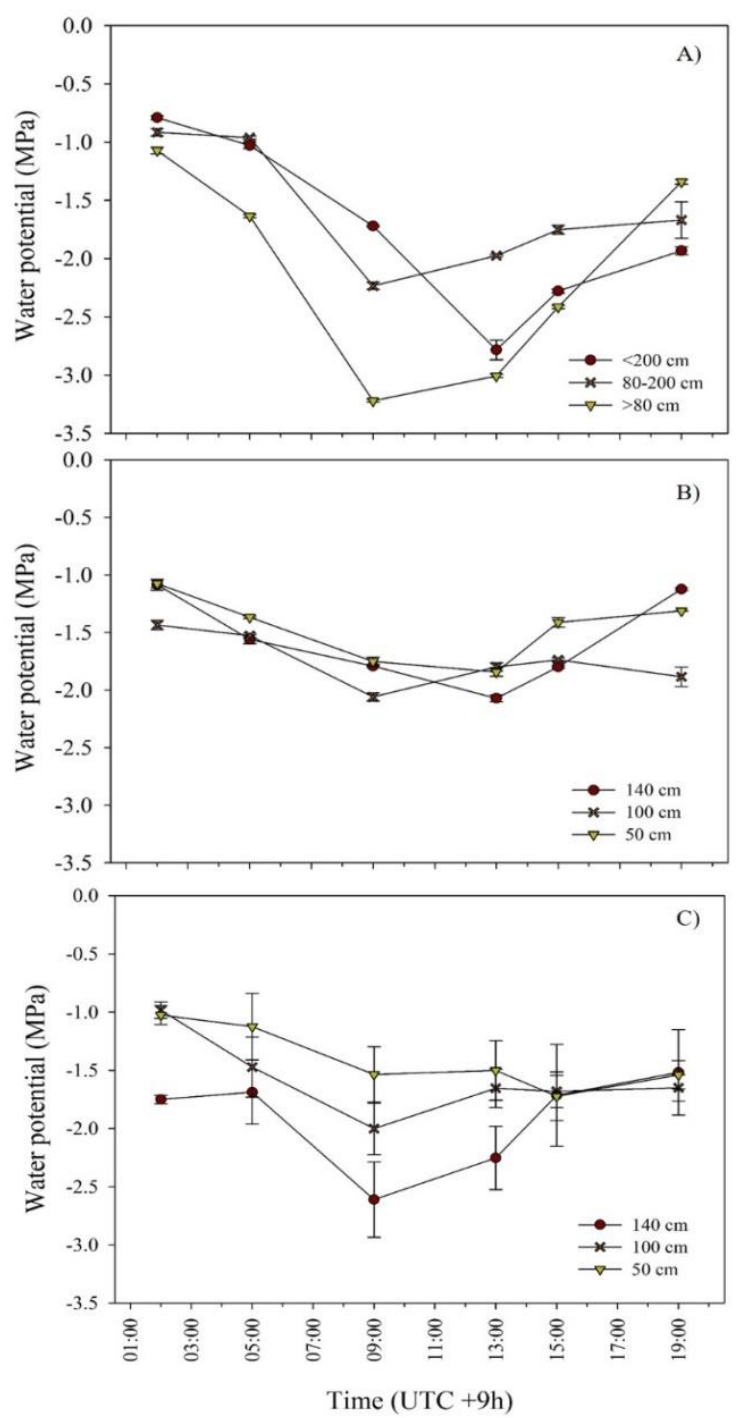

Figure 3. A) Diurnal variation on shoot water potential of natural forest trees by tree height. B)

Diurnal variation of shoot water potential of containerized trees by height. C) Diurnal variation of shoot water potential of direct seeding trees by height. The bar indicates the standard error.
Shoot water potential measurement among study sites by tree height and time of measurement differed significantly $(\mathrm{p}<.026 ; \mathrm{p}<.0001)$. The mean shoot water potential of trees from natural forests ($1.81 \pm 0.03 \mathrm{MPa})$, in the seedlings planted $(-1.59 \pm 0.03$ $\mathrm{MPa})$, and direct seeding $(-1.63 \pm 0.21 \mathrm{MPa})$ (Figure 4), respectively.

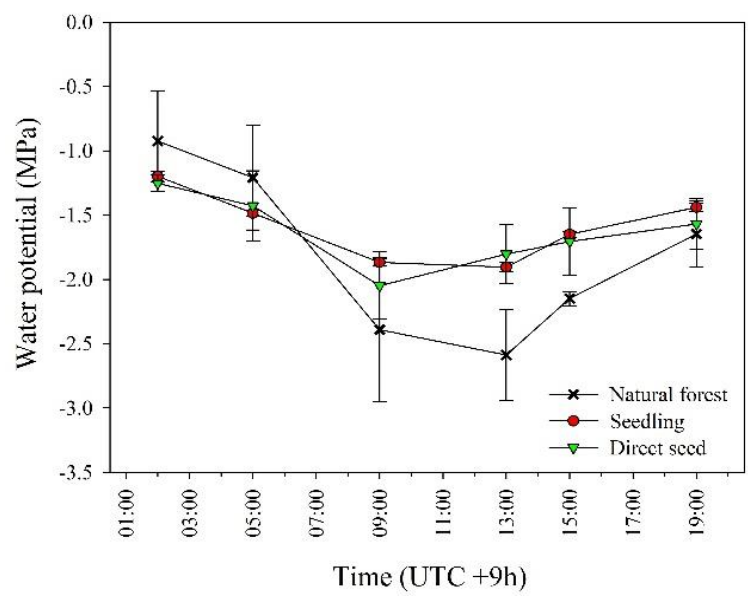

Figure 4. Diurnal variation of shoot water potential by study sites. The bar indicates the standard error.

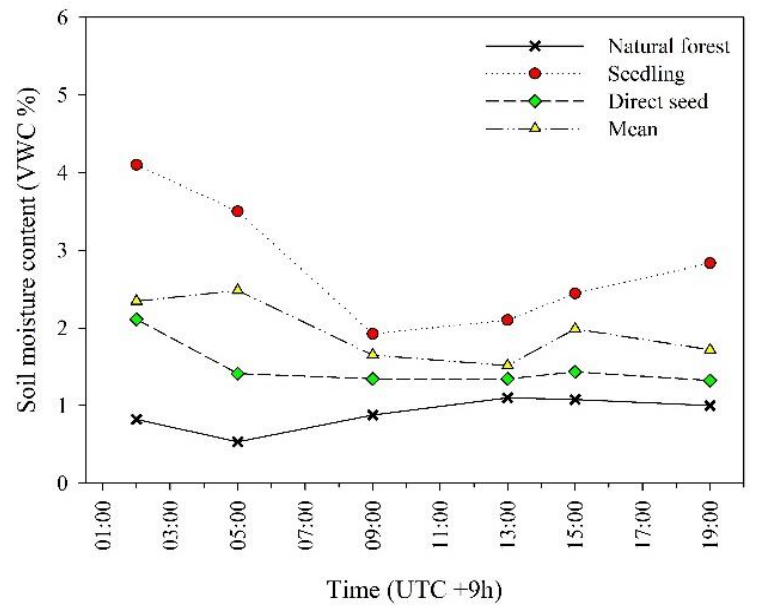

Figure 5. Diurnal variation of soil moisture content by study sites.

The soil moisture content differed among study sites $(\mathrm{p}<.02)$, but did not differ between measurement hours $(\mathrm{p}=.75)$, values of soil moisture recorded in natural forests $(1.03 \pm 0.13 \%)$, seedling $(2.74 \pm 0.20 \%)$, or direct seeding $(1.49 \pm 0.14 \%)$ (Figure 5).

Measurements of shoot water potential revealed that most trees were subjected to water shortages at 09:00 and 13:00, then water stress gradually decreased from 15:00 onwards. The results of the study show that the soil moisture content, relative humidity and air temperature, as well as the daily rhythm of the shoot water potential have the same 
trend. As soil moisture decreases, shoot water potential decreases, which is consistent with the results of other researchers $[20 ; 21]$. According to these studies, when the soil moisture content decreased by $1 \%$ or more, the osmotic potential of the cell decreased by $-3.41 \mathrm{MPa}$ or more. Under these conditions, cell turgor cannot be recovered and young trees are more likely to be affected than mature trees. Comparing the shoot water potential of seedlings planted with direct seeding, it was observed that containerized seedlings or underground root system trees have a greater ability to reduce and retain water that evaporates from the shoot surface (succulents). Additionally, natural forest trees are affected by water stress due to low precipitation according to the low value of shoot water potential. Moreover, this indicates that seedlings and direct seeding with regular irrigation and a balled planting root system is more suitable in arid regions.

\section{CONCLUSION}

A comparative study of the shoot water potential of natural trees, seedlings and direct seeding showed that juvenile trees (up to $80 \mathrm{~cm}$ ) were more susceptible to water shortages than young and mature trees (over $80 \mathrm{~cm}$ ). As young trees grew taller, their susceptibility to water stress increased. Naturally occurring trees had lower shoot water potential values and were more susceptible to water deficits than regularly watered trees. In the case of planted trees, watering the hole irrigation may be more effective than spraying water irrigation, as measured by shoot water potential measurements. This is the first study of natural and plantation saxaul, and will be the beginning of a study to assess the resilience and adaptability of seedlings to drought and other natural factors.

\section{ACKNOWLEDGMENTS}

This study was conducted in support of the joint Mongolia-Korea "Greenbelt" Plantation Project supported by the Korea Forest Service, Republic of Korea. Our sincere thanks to Jonathan Chamber who is a researcher of the IGG, MAS for valuable comments and language editing of our manuscript.

\section{REFERENCES}

[1] Z. Huang, Z. Xinshi, Z. Guanghua, and G. Yitzchak, "Influence of light, temperature, salinity and storage on seed germination of Haloxylon ammodendron," J. Arid Environ., vol.
55, no. 3, pp. 453-464, 2003, doi: 10.1016/S0140-1963(02)00294-X.

[2] P. Casati, C. S. Andreo, and G. E. Edwards, "Characterization of NADP-malic enzyme from two species of Chenopodiaceae: Haloxylon persicum (C4) and Chenopodium album (C3)," Phytochemistry, vol. 52, no. 6, pp. 985-992, 1999, doi: 10.1016/S0031-9422(99)00355-6.

[3] G. Gal, Basics of proper use and improvement of fire and saxaul forest resources. Ulaanbaatar, Mongolia: Mongolian Academy Sciences, 1968.

[4] S. M. Yang and I. Furukawa, "Anatomical features of a rayless woody xerophyte Haloxylon ammodendron," Sand Dune Res., vol. 49, pp. 99-104, 2003.

[5] H. Heklau, P. Gasson, F. Schweingruber, and P. Baas, "Wood anatomy of Chenopodiaceae (Amaranthaceaes. 1.)," IAWA J., vol. 33, no. 2, pp. 205-232, 2012.

[6] J. Li, H. Wada, and H. Matsuzaki, "Radial growth rate through successive cambia in Haloxylon ammodendron (Chenopodiaceae) from the Gurbantünggüt Desert, Northwestern China, determined by a series of radiocarbon dating," Geochem. J., vol. 49, no. 1, pp. 39-51, 2015, doi: 10.2343/geochemj.2.0328.

[7] Y. Y. Song and C. B. Zhou, "Multiple bands characteristics of tree-ring and age of Haloxylon ammodendron in Gurbantunggut Desert," Pakistan J. Bot., vol. 47, no. 2, pp. 615-622, 2015.

[8] Z. Huang and Y. Gutterman, "Artemisia monosperma achene germination in sand : effects of sand depth , sand / water content , cyanobacterial sand crust and temperature," J. Arid Environ., pp. 27-43, 1998, doi: 10.1006/jare.1997.0329.

[9] D. J. Bedunah and S. M. Schmidt, "Rangelands of Gobi Gurvan Saikhan National Conservation Park, Mongolia," Rangelands, vol. 22, no. 4, pp. 18-24, 2000, doi: 10.2458/azu_rangelands_v22i4_bedunah.

[10] Y. Sheng, W. Zheng, K. Pei, and K. Ma, "Genetic variation within and among populations of a dominant desert tree Haloxylon ammodendron (Amaranthaceae) in China," Ann. Bot., vol. 96, no. 2, pp. 245-252, Aug. 2005.

[11] T. Enkhchimeg, B. Ser-Oddamba, A. Oyuntugs, S. Zoljargal, D. Narantugs, and N. Batkhuu, "Population demographic characteristics of 
Haloxylon ammodendron (C.A. Mey.) Bunge ex Fenzl in Gobi Desert of Mongolia," Mong. J. Biol. Sci., vol. 18 , no. 2, pp. 29-40, 2020, doi: 10.22353/mjbs.2020.18.13.

[12]H. Von Wehrden, K. Wesche, and G. Miehe, "Plant communities of the southern Mongolian Gobi," Phytocoenologia, vol. 39, no. 3, pp. 331376, 2009, doi: 10.1127/0340-269X/2009/00390331.

[13] Khaider, B. Nyam-osor, E. Tsedensodnom, and S.-O. Byambadorj, "Saxaul restoration activities in Southern Gobi Desert of Mongolia and their growth performances," in International Workshop on Restoration and Sustainable Management of Dryland Forests in Central and Northeast Asia, 2019, pp. 77-84.

[14] Khaulenbek, K. Ihanbai, and N.-O. Batkhuu, Saxaul Forest in Mongolia: Ecosystem, resources, values. Ulaanbaatar, Mongolia: UN REDD+ programme, 2018.

[15] M. Olszewska, S. Grzegorczyk, J. Olszewski, and A. Bałuch - Małecka, "A comparison of the response of selected grass species to water stress," Grassl. Sci. Pol., vol. 13, pp. 127-136, 2010.

[16] R. Rabas and C. E. Martin, "Movement of water from old to young leaves in three species of succulents," Ann. Bot., vol. 92, no. 4, pp. 529536, 2003, doi: 10.1093/aob/mcg171.

[17] M. J. Savage, H. H. Wiebe, and A. Cass, "In Situ Field Measurement of Leaf Water Potential Using Thermocouple Psychrometers," Plant Physiol., vol. 73, no. December, pp. 609-613, 1983, doi: 10.1104/pp.73.3.609.

[18]P. F. Scholander, H. T. Hammel, E. a. Hemmingsen, and E. D. Bradstreet, "Hydrostatic Pressure and Osmotic Potential in Leaves of Mangroves and Some Other Plants," Proc. Natl. Acad. Sci. U. S. A., vol. 52, no. 1, pp. 119-125, 1964, doi: 10.1073/pnas.52.1.119.

[19] SAS Institute Inc, "SAS software 9.4," SAS Institute Inc. Cary, NC, USA. USA, pp. 1-25, 2014.

[20] W. B. Yang, W. Feng, Z. Q. Jia, Y. J. Zhu, and J. Y. Guo, "Soil water threshold for the growth of Haloxylon ammodendron in the Ulan Buh desert in arid northwest China," South African J. Bot., vol. 92, pp. 53-58, 2014, doi: 10.1016/j.sajb.2014.02.001.

[21] G. Q. Xu, Y. Li, and H. Xu, "Seasonal variation in plant hydraulic traits of two co-occurring desert shrubs, Tamarix ramosissima and Haloxylon ammodendron, with different rooting patterns," Ecol. Res., vol. 26, no. 6, pp. 10711080, Nov. 2011. 